\title{
EDITOR'S FOREWORD
}

On the Way to Democracy by Professor Fuat Köprülü is a collection of political articles written for the daily newspapers of Turkey in the years from 1945 to 1950. In these articles Professor Köprülü, who was one of the founders of the Democrat Party, discusses the questions Turkey faces in the development of democracy and endeavors to enlighten the Turkish people on its meaning and to advance them on its path. At the same time the articles constitute a document on the latest stage of the Westernization of the Turks. The lack of a monograph in either of these fields makes Professor Köprülü's book doubly valuable.

We can summarize what we know in the areas of Westernization and democracy in Turkey as follows:

Many scholars have studied and published material on the Westernization movements in the Ottoman Empire in the nineteenth and twentieth centuries. As a result it is now universally accepted that the Empire, which had always been in close and continuous contact with European civilization, came under the immediate influence of that civilization in the beginning of the eighteenth century. However, the European influence that emerged among the aristocracy of the country at that time was nothing more than a passing fashion having to do only with form. The Ottoman Empire being fundamentally a military state, European influence, though at first very superficial and limited, had its actual beginning in the military field. Because the governing group were struck principally by the backwardness of the army and navy, they perceived the need of reform most clearly in this field. Meanwhile the printing press was introduced, and a few works of history, geography, and science were translated into Turkish. Yet these moves did not arouse much reaction in Turkish intellectual and artistic life, and Turkish society did not profit as much as it might have from eighteenth-century Western civilization. 
Ottoman society, which was still medieval, took steps toward joining European civilization, but this process did not happen spontaneously or naturally. Turkish society was forced to accept certain Western concepts because of pressures from without.

After modest beginnings, revolutionary developments in the Westernization movement followed one after the other in the periods of Mustafa III, Selim III, and Mahmut II. Succeeding these, the Tanzimat and in particular the First Constitution each marked a clear-cut period of Westernization. Though political Westernization could only seethe underground during the harsh administration of Abdülhamit II, it seemed to gain momentum again after the proclamation of the Second Constitution in 1908. In the Republic period beginning after the War of Independence, the revolutionary movement brought about certain innovations, mostly in cities and towns, which could hardly have been imagined in earlier years. Under the aegis of the Democrat Party movement after World War II, many of these transformations spread to the villages, and thus the Westernization movement became general throughout Turkey, reaching its highest point so far.

At its start Westernization in Turkey held to a narrow field. In the eighteenth century and the beginning of the nineteenth it was a movement of rulers and grand viziers. From the Tanzimat to the Republic a small educated group took the place of the rulers. This means that until 1920 it was a movement that spread from high to low. In the years after 1920 not only did the educated group substantially increase, but as a result of the reforms of the Republic the people also became greatly interested in the affairs of the country. As the people gained awareness, one began to perceive a movement directed from low to high and a resultant desire for change. Every unpartisan observer who has concerned himself with Turkish affairs knows how strong this desire is today in even the smallest Turkish village and how powerful is the pressure directed by the village upon the central administration.

One result of the Westernization movement was the existence in Turkey of a kind of duality in military, judicial, administrative, and educational matters until the proclamation of the Republic. This duality, that is to say 
the existence of institutions founded according to Western concepts side by side with medieval Muslim institutions, was a consequence of the necessities of history.

Fuat Köprülü, in an article which appeared in 1945, tersely explains the most striking difference between the civilizations of East and West:

In any sort of comparison that can be made between Greek civilization, which is the mother of today's emphasis on human values, and ancient China, Iran, Mesopotamia, and Egypt, in a word the old civilizations of the East, this great difference strikes the eye even at first glance.

In these great civilizations that produced the magnificent empires of the Ancient East, the rulers were raised above mankind and deified; that is they were God, or the son of God, or God's representative on earth. It can thus be easily understood how this view gave birth to a system of fearful oppression and despotism... Yet in Greek civilization we see that the gods were, on the contrary, humanized. Whereas the first of these two opposing views gave birth to despotism, oppression, dictatorship, and physical and spiritual slavery, the second opened the road to physical and spiritual liberty, to democracy, and to freedom of thought. (Vatan, September 19, 1945.)

As to democracy in Turkey, we know that the first traces of it were encountered in the years of the Tanzimat and that its development was accelerated in the periods of the First and Second Constitutions. The First Grand National Assembly that created the New Turkey established sounder foundations for democracy. The 1950 election gave rise to the brightest period of democracy in Turkey yet known.

At the beginning of the nineteenth century we meet for the first time in Turkey - albeit in indistinct form - the concept of a regime of popular will and constitutional law, which is one of the most important principles of democracy. In this period statesmen, writers, and particularly reformers began to perceive the importance of rights and liberty. Yet at the start the concept of rights and liberty was understood only in the sense of the equality and security of the citizen before the law, and of self-defense against arbitrary and illegal acts of government. The idea that the citizen can take a part and play a role in government appeared much later. Among the men who projected the ideas that led to the successes of constitutional government in the twentieth century we can mention Alemdar Mustafa Pașa, 
Sadık Rifat Pașa, Reșit Pașa, Abdülmecit, Ziya Pașa, Namık Kemal, and Mithat Pașa.

In spite of all the oscillations of Turkish democracy, it has followed a continuously rising path. In other words, although its years of progress have been interspersed with years of decline, it is clear that every period of progress has reached a higher level than the preceding one. These fluctuations, which have been witnessed since the beginning of Westernization movements in Turkey, are especially obvious in the democratic drives of the constitutional periods. The enthusiasm of the first constitutional period was followed by the administration of Abdülhamit II. The fact that the revolutionary group consisted of a few inexperienced people was an important factor in the short duration of this period. Although the second constitutional period lasted a little longer, it too ended in failure and a broken dream, because its partisans during the Balkan War and the Second World War were excessively weak and raw. The Constitution remained on paper, elections turned into electioneering maneuvers, and constitutional government abdicated its place to a military junta.

As to the period of the Republic, Fuat Köprülü has this to say:

The first constitution, ${ }^{*}$ which is the main support of the Republic regime in Turkey, was a very glorious and sincere manifestation of the democratic spirit in the field of political law. With this law, national sovereignty was secured in so broad a form as to arouse the envy of many of the democracies of the old and new worlds. It is unfortunate that this situation did not last! This atmosphere of democracy slowly disappeared, for a variety of reasons which are remote from the main subjects we are discussing here; no trace of freedom of thought, freedom of criticism, or freedom of the press remained. Because the Constitution remained a barren form, the arena was gradually captured by certain restricting and constricting laws completely contrary to the original spirit. Certain laws such as the new Press Law, the new Law of Association, the new Police Law, and similar laws liquidated political freedom. In this situation it was not possible for a single-party Assembly properly to exercise its duty of control, and the spirit of democracy was thoroughly injured. (Vatan, September 25, 1945.)

- I.e., the constitution of the Republic. 
The years preceding and following the 1950 election are well known as a bright period in the history of Turkish democracy. However, it is also known that recent years mark a period of decline. Although these years are still too close to lend themselves to the comments of historians, this much is certain: The heroes of one period of decline, be they civil or military, are not different in their shortcomings, errors, and virtues from the heroes of any other period of decline.

This interspersing of the links of progress and decline appears not only in the general history of Turkish democracy, but also in its specific elements, though perhaps less obviously. For example the 1876 Constitution was put into force with great enthusiasm three times, but because the expected result was not forthcoming it met with failure each time. Yet the deficiency cannot be imputed to the concept of democracy. Likewise the failure of the Constitution cannot be ascribed to a fault or inadequacy in constitutional government. Rather the lack of success proceeds from weakness of application. When we compare the pre-1945 or post-1955 administrative laws with the original Constitution, a great contrast is immediately apparent.

General elections and other elements of political democracy, such as the multi-party system, are still so new in Turkey that this is not the time to put forward observations on the subject. Although from 1876 to 1950 Turkey held fourteen general elections, only in 1908, 1912, 1919, 1946, and 1950 did so many as two competing "parties" participate. In only two of these elections - 1946 and 1950 - were the participants political parties established according to the concepts of Western democracy. Political parties began to be set up in Turkey only in 1945. The Democrat Party was formed on the seventh of January, 1946, and the People's Party of the Republic took the form of a political party in its May convention in 1947.

The Center of Turkish Studies of Columbia University, in order to facilitate the investigation of the later periods of the development of Westernization and democracy in Turkey, has endeavored to publish in book form the political articles of Professor Fuat Köprülü, who played an important role 
in the struggle for democracy which was instituted after World War II. The result is the 908-page collection of 283 articles which follows this foreword.

This rich collection clearly proves that Fuat Köprülü, as party ideologist, gave voice to the concepts for the democratic movement that began in Turkey after the Second World War. This movement was prompted by a complicated drive that owed its existence to various internal and external factors impossible to discuss in a short foreword. And Köprülü, by devoting himself to writing in order to explain the meaning of the movement, undoubtedly became the leading figure of it. This situation clarifies his political role in the years between 1945 and 1955, and also throws light on his resignation from the cabinet, which was not understood by many when it was given in 1957. When many of the concepts which had been established as he had formulated them were departed from, Köprülü felt that, in the capacity of a genuine democrat, he could do nothing but withdraw.

In his articles Köprülü the scholar demonstrates that he is not only a profound thinker who can give lucid and pleasing form to his thoughts, but also one of the few statesmen developed in Turkey during the Constitutional Period and the Republic.

At the same time these articles are an extremely rich source for the understanding of today's Turkey. Köprülü, whose writing is concerned with many vital Turkish questions, offers extensive material both on Turkish democracy and on Turkish history after the Second World War. The fact that the writer was a participant in the events gives a special value to these articles and likewise throws light on many of the actual causes of events.

For example Köprülü sees in mode of thought (zihniyet) the reasons for the fluctuations in the progress of Turkish democracy. As a pupil of Alfred Fouillet and Ziya Gökalp, Köprülü is a partisan of the idée-force school. He believes that first of all a revolution in ideas and mode of thought is needed in Turkey, and that without it there can be no positive results.

As in everything else, in the intensity of revolution it is easy to destroy and difficult to construct. We must admit that the government of the Republic 
has been successful in liquidating the old values, but it has not shown the same strength from the viewpoint of being constructive. The fact that the intellectual and political men of our country have had a very elementary and superficial understanding of Western civilization and Western institutions and have known almost nothing at all about our national past has been the principal factor in this matter. (Son Saat, April 1, 1947.)

Köprülü dwells insistently on the same idea in another relationship:

Western mode of thought and the basis of Western endeavor are still entirely unknown in our country. Every minister considers himself the greatest expert as soon as he sits in his chair. He goes out on investigating excursions, he gives directives. From time to time he sets up a committee of so-called specialists and a board of scholars composed of people he is sure will not object to his ideas, and has them endorse his thinking. Parade and the spirit of despotism, a mode of thought that will not put up with criticism, and eagerness to employ friends and acquaintances go on uninterruptedly. No matter how much the persons may change, as long as this evil Eastern mode of thought is not abolished it will never be possible to develop the country or to bring about a true revolution. However, it is a national duty for all patriotic Turks to work together on the road of this intellectual and moral revolution, which can be brought about only by a democratic regime. (Kuvvet, August 1, 1947.)

The fact that mode of thought has played the main role in the recurring crises in Turkish democracy indicates that Köprülü's criticism has a value transcending periods and persons. For example, his observations on the period of Union and Progress are valid for many other periods also:

In fact single-party mode of thought and power that relies on a single party have a psychology all their own. Conversely, a mind that has absorbed a democratic education cannot easily understand the state of mind formed under the influence of long habit and old traditions that go back centuries. As an example, let us take the former Union and Progress administration and the people who headed it: This administration and these men came to power as the result of a military revolt. They were generally patriotic, honorable men who scorned material gain, but they could not be saved from the evil influence of a narrow viewpoint and the fanaticism of secret revolutionary activity. They looked with suspicion on everything outside their own frame of reference; they suspected every criticism. They conceded the ability to govern the country only to themselves and were able to find no men of capacity and character outside their own group. (Son Saat, March 12, 1947.) 
He says that the "statesmen" preceding 1946 had no sense of responsibility to the nation, a judgement that could well be applied to the "statesmen" of a good many other periods too:

Have not certain men, who have been carried to their greatest positions of responsibility, said for long years, like parrots, that they have come to their positions by the command and with the approval of their elders, and moreover have they not kept on repeating that, like soldiers, they have only been changing the guard? (Kudret, December 3, 1947.)

The village question, one of the main problems of Turkish democracy, is also in the end a question of mode of thought. We know that the Anatolian villager was proclaimed "the master of the country" by the Republic regime. We also know that this same regime sent out government officials and party men to push the villager in order to implement its policies. To use Fuat Köprülü's words :

It is clear that, with us, the interpretation of government is still not very different from the mode of thought of the period of the old Ottoman Empire and that external innovation has not, up to now, entirely changed the old spirit under the varnish of modernism. Before the Tanzimat the Ottoman government divided the people of the country into two main groups: The Osmanlss were a distinct and privileged group who procured their means of livelihood, in whatever form, from the state budget; those who were outside this group and who were taxed with financial and physical burdens up to their shoulders were considered râyas. (Kuvvet, February 22, 1947.)

In reply to this point of view, which is shared by a good many people, Köprülü says in other articles:

We can trust, in every way, the common sense, the moderation, the equilibrium, and the unshakable determination of our people, who have more national and political comprehension than those who would presume to be their guardians. (Vatan, September 25, 1945.)

Thanks to the trials of everyday life, they have taken the measure of the government with an infallible instrument, the ability to distinguish between good and evil, right and wrong, and truth and lies in national affairs; and what is more, they are not hesitant in showing, by every means, that they are absolutely determined to obtain the rights and liberties of citizenship 
to which they are entitled, and that no power can prevent it. (Kuvvet, April 4, 1947.)

The Turkish villager, who is no less patriotic and politically mature than the city man, presents an intelligent, nationally unified point of view in matters pertaining to the benefit of the country. However, he complains because of the incapacity, impotence, and bad administration of the party in power and especially because of its insistence on withholding his rights and his liberties. (Vatan, April 4, 1947.)

In order not to lengthen this foreword, let us be content to note only one more point: This mode of thought is a general mode; therefore no particular persons or groups can be held responsible. As Köprülü emphasizes:

It is wrong and unjust to try to load responsibility onto persons or groups because of the mistakes of past years. All these mistakes, like the glories of the War of Independence and of the Republic, are widespread and shared. (Vatan, October 29, 1949.)

As to the procedure followed in collecting and publishing these articles: We have tried to include in this volume all the political articles of Fuat Köprülü written in Turkish between the years 1945 and 1950. If one puts aside the matter of spelling, the articles published here conform to the originals in their entirety. When an article originally appeared in several newspapers, in general the newspaper has been selected which published the article the first time. In doubtful cases the singling-out of the newspaper has been done by the author himself. Sentences which could not be read or which were not clear have been referred to the author for clarification. The articles are arranged according to their dates of publication. This method has been chosen in order to assure the unity of those articles which were originally published in instalments and to make clear the march of events discussed. For easy use of the articles, indices have been added at the end of the volume.

For making possible the appearance of these articles in book form, through both his material help and his moral backing, I want to thank the former director of the Near and Middle East Institute of Columbia University, Professor Schuyler C. Wallace. 
In addition I owe thanks to my friends Suzan Akkan, Kathleen R. F. Burrill, Fanny Davis, Hasan Eren, Eva Halasi-Kun, Talat Halman, Uluğ İğdemir, Sadrettin Karatay, Orhan Köprülü, Aert Kuipers, Sami N. Özerdim, and Fevziye Abdullah Tansel, who spared no help in order that the articles published in this book might appear in as correct a form as possible.

I would also like to mention here, with thanks, the name of Peter de Ridder. Our friendship and the joint work of Columbia University and Mouton \& Co. expressed in the Publications in Near and Middle East Studies began with Köprülü's On the Way to Democracy.

Finally, I want to express my thanks to Professor Fuat Köprülü, the great scholar who has international fame as the founder of Turkic studies in Turkey, for his close friendship and the confidence he has shown me by consenting to the publication of these political articles, which constitute a stage on the way to democracy in contemporary Turkey.

THE EDITOR 